\title{
ANALYSIS OF THE IMPACT OF OIL VISCOSITY ON THE VIBROACOUSTIC SIGNAL OF A PLANETARY GEARBOX OPERATING AT VARIABLE LOAD
}

\author{
Pawel PAWLIK
}

\begin{abstract}
AGH University of Science and Technology, Faculty of Mechanical Engineering and Robotics Department of Mechanics and Vibroacoustics al. A. Mickiewicza 30, 30-059 Kraków, Poland e-mail: pawlik@agh.edu.pl
\end{abstract}

\begin{abstract}
The paper presents the analysis of the impact of oil viscosity on the vibroacoustic signal generated by a planetary gearbox operating at variable load. A diagnostic experiment was conducted at the laboratory rig for testing planetary gearbox which was lubricated with a dedicated ISO 150 viscosity class oil and much lower viscosity class $5 \mathrm{~W} 40$ oil. The gearbox was subjected to two types of sinusoidal load and to a random load corresponding to the load of the main gearbox of the KWK 1500s bucket wheel excavator used in opencast mining. The diagnostic method was proposed based on the analysis of the dependence of the gearbox characteristic orders amplitudes on the load. The effectiveness of the method in detecting the changes in vibration acceleration signals caused by the oil viscosity changes was proved.
\end{abstract}

Keywords: planetary gearbox, gearbox lubrication, order analysis, variable load

\section{ANALIZA WPŁYWU LEPKOŚCI OLEJU NA SYGNAŁ WIBROAKUSTYCZNY PRZEKŁADNI PLANETARNEJ PRACUJĄCEJ PRZY ZMIENNYM OBCIĄŻENIU}

\section{Streszczenie}

Praca przedstawia analizę wpływu lepkości oleju na sygnał wibroakustyczny generowany przez przekładnię planetarną pracującą przy zmiennym obciążeniu. Przeprowadzono eksperyment diagnostyczny na stanowisku laboratoryjnym do badania przekładni planetarnej, która smarowana była olejem dedykowanym o klasie lepkości ISO 150 oraz olejem o dużo niższej klasie lepkości 5W40. Przekładnię poddano dwóm typom obciążenia o charakterze sinusoidalnym oraz dla losowego obciążenia odpowiadającego obciążeniu przekładni głównej koparki kołowej KWK 1500s występującej w przemyśle odkrywkowym. Do analizy zaproponowano metodę diagnozowania bazującą na analizie zależności amplitudy rzędów charakterystycznych przekładni od obciążenia. Wykazano skuteczność metody w wykrywaniu zmian w sygnale przyśpieszenia drgań spowodowanych zmianą lepkości oleju.

Słowa kluczowe: przekładnia planetarna, smarowe przekładni zębatej, analiza rzędów, zmienne obciążenie

\section{INTRODUCTION}

The paper presents the analysis of the impact of oil viscosity on the vibroacoustic signal generated by a planetary gearbox. The lubrication method and the lubricant have a decisive impact on the gearbox operation, a broad review of papers on this topic can be found in [1]. The type of lubricating oil has a significant impact on the efficiency [2]. On the other hand, the lubrication method affects the capacity and dynamic properties [3][4][5] which are closely related to the vibroactivity [6][7][8]. This leads to the conclusion that the lubrication method affects the vibroacoustic signal of a gearbox. This conclusion was proved in [9] where the amplitude of a two-stage gearbox was reduced by $15 \%$ when a higher viscosity oil was used.

The paper aims at the analysis of the impact of oil viscosity on the vibroacoustic signal generated by a planetary gearbox operating at variable load.
An attempt was made to identify the components of the vibroacoustic signal carrying information about the change in oil viscosity. Variable loads occur frequently in industrial conditions, e.g. in heavy industry. Vibroacoustic signals are often used to diagnose the technical condition of machines. However, the change in load significantly affects standard diagnostic parameters such as RMS or peak value. Advanced signal analysis methods should be used for diagnosing the machines operating at variable load. Synchronous methods are widely used and allow synchronizing the signal containing diagnostic information with variable machine speed. The synchronous methods were known as early as in the $1980 \mathrm{~s}$, and their implementation involved synchronous signal sampling during the measurement [10][11]. Currently, the synchronous methods involve the analysis of recorded signal and the application of such analytical methods as decimation [12] [13] 
[14], resampling [15][16] or Gabor transform [17]. Synchronous methods allow eliminating the impact of the changes of rotational speed by transition from the frequency domain to the order domain related to the machine shaft rotation. Such methods significantly facilitate the diagnostics, however do not solve the problem of varying amplitude of the signal characteristic components caused by the load, shown in [18][19]. Variable load affects, inter alia, the amplitudes of characteristic orders, and such change can be misinterpreted e.g. as damagerelated. The problem can be solved by studying the relationship between the amplitudes of characteristic orders as a function of load for the correct operation of machine and by examining the deviations from this relationship as was done in [20][21].

The paper presents the analysis of the impact of oil type on the characteristic orders of a planetary gearbox operating at variable load. The diagnostic method was proposed based on the analysis of the dependence of the gearbox characteristic orders amplitude on the load. Characteristic orders which may carry information about the oil viscosity are indicated. In the proposed method, deviations from the standard dependence of the order amplitude on the load are observed, instead of the mean amplitude of the characteristic order determined from the order spectrum for a specific time window. The effectiveness of the proposed method was tested on the laboratory rig for a sinusoidal load and for a random load corresponding to the load of the main gearbox of the KWK 1500s bucket wheel excavator used in opencast mining. The effectiveness of the method in detecting changes in the vibration acceleration signal caused by a change in oil viscosity has been demonstrated.

\section{LABORATORY RIG}

The impact of the oil viscosity on the vibroacoustic signal was examined at the laboratory rig comprising a TRAMEC EP 90/1 planetary gearbox (ratio 4:1) operating as a reducer. The gearbox was driven by an asynchronous motor controlled by a frequency converter. The load was another induction motor connected with the gearbox via a jaw coupling. The load motor was also controlled by a frequency converter which allowed setting any system loading function.

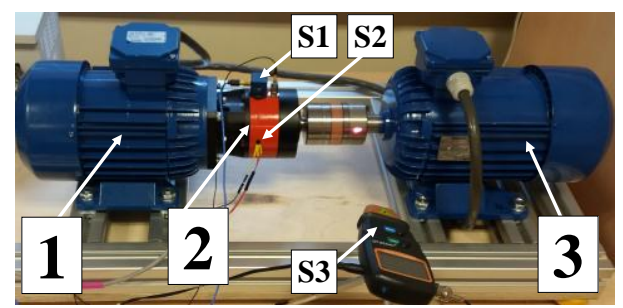

Fig. 1. Laboratory rig, 1) drive motor, 2) planetary gearbox, 3) motor which is the load, S1) acceleration sensor, S2) temperature sensor, S3) tachometer
The acceleration signals were recorded with the $51200 \mathrm{~Hz}$ sampling frequency on the gearbox housing using a triaxial PCB356B08 sensor. The revolution marker of the gearbox output shaft was recorded simultaneously using a laser tachometer. The laboratory rig is presented in Fig. 1.

\section{EXPERIMENT}

The experiment involved recording the vibration acceleration signals, revolution marker of the gearbox output shaft for two lubricants. First to be used was the dedicated gear oil Mobil SHC 629 with ISO 150 viscosity class. Then, the lubricant was changed to Elf Evolution 900 SXR with 5W40 viscosity class and the experiment was conducted at the same operating conditions. Finally, the lubricant was again Mobil SHC 629 to confirm the initial results.

The measurements for two lubricants were made for a sinusoidal load and for a random load recorded in industrial conditions by the monitoring system for the main gearbox of the KWK 1500 s bucket wheel excavator. The rotational speed diagram for sinusoidal load is presented in Fig.2, and for random load in Fig.3. In the analysed case, the rotational speed changes are inversely proportional to the load torque because the motor is supplied with the voltage of constant frequency and the load variations are set by reducing the voltage frequency supplied to the other motor. The speed changes in the 726-745 [rpm] range correspond to the load changes of 4.0-1.8 [Nm]. All measurements were made when the gearbox heated up to $40^{\circ} \mathrm{C}$ because the temperature has a significant impact on the order amplitude values [22]. The kinematic viscosity of the oil also changes with temperature. The viscosity classes of the oils used and kinematic viscosity at $40^{\circ} \mathrm{C}$ are shown in Table 1.

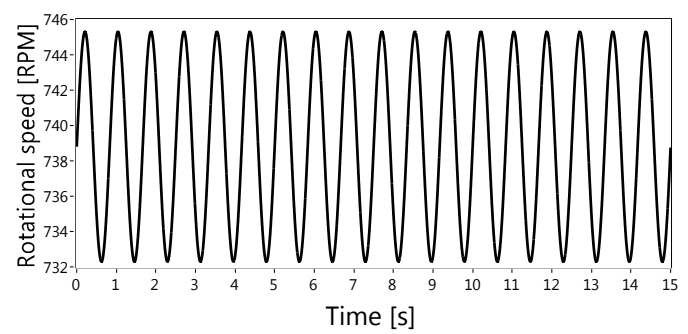

Fig. 2. Rotational speed under sinusoidal load 3.9-1.8 [Nm]

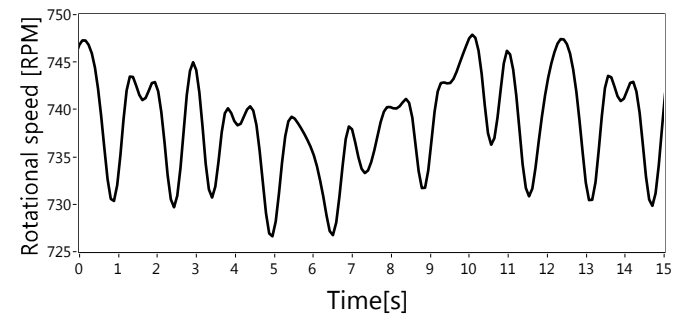

Fig. 3. Rotational speed under random load corresponding to the load of the main gearbox of the KWK 1500s bucket wheel excavator 
Table 1 . Kinematic viscosity of the oils used

\begin{tabular}{|c|c|c|}
\hline Oil & $\begin{array}{c}\text { Viscosity } \\
\text { class }\end{array}$ & $\begin{array}{c}\text { Kinematic viscosity } \\
\text { at } 40^{\circ} \mathrm{C}\left[\mathrm{mm}^{2} / \mathrm{s}\right]\end{array}$ \\
\hline $\begin{array}{c}\text { Mobil SHC } \\
629\end{array}$ & ISO 150 & 150 \\
\hline $\begin{array}{c}\text { Elf Evolution } \\
\text { 900 SXR }\end{array}$ & $5 \mathrm{~W} 40$ & 90 \\
\hline
\end{tabular}

\section{DATA ANALYSIS}

The analysis of the oil impact on the vibroacoustic signal was performed using the method based on the relationship of the amplitudes of characteristic orders as a function of load. This method was described in detail in [20] where it was used to diagnose the motor misalignment and incorrect fixing.

In the first stage, the vibration acceleration signal is synchronized with the revolution marker signal. The synchronization involves resampling the vibration signal relative to the shaft rotation angle (in the analysed case, 168 samples per revolution of the output shaft). Such resampled signal can be Fast Fourier Transformed (FFT) to obtain the order spectrum. The order spectrum presents the signal components synchronized with shaft revolutions. However, the order analysis does not solve the problem of diagnosing the machines operating at variable load, because the characteristic order amplitude changes along with the change of load. Consequently, the paper focuses on the analysis of amplitude as a function of rotational speed. In the analysed case, the rotational speed changes are inversely proportional to the load torque because the motor is supplied with the voltage of constant frequency. The load variations are set by reducing the voltage frequency supplied to the motor which performs the function of the load.

In the next stage, the relationship between the orders amplitude and the rotational speed is expressed as a function. It can be done using the approximation with an nth order polynomial; the algorithm is presented in Fig.4.

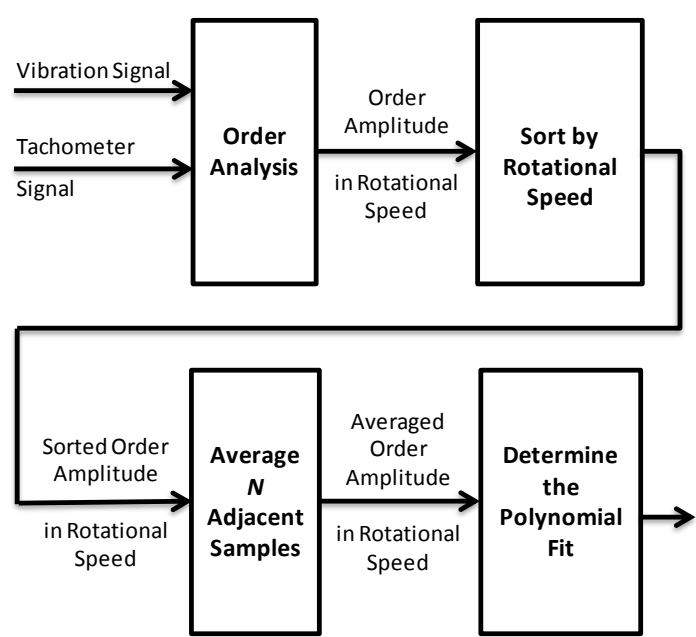

Fig. 4. Algorithm for determination of functional relationship between the rotational speed and characteristic orders
The order analysis allows the determination of the value of the order amplitudes depending on the rotational speed. These dependencies are determined with the resolution of one revolution of the output shaft. Then the amplitude values are sorted in ascending order depending on the rotational speed. In the next step, the averaging of $N$-consecutive samples is performed. In the presented case, the value of $N=15$. In the last step, the $n$th order polynomial fit is performed.

In order to evaluate the correctness of fit with an nth order polynomial, 95\% confidence intervals were determined based on standard deviations of $\mathrm{N}$ element sets of samples from which determined was the average in the algorithm shown in Fig.4. Such confidence interval allows determining the degree of polynomial which fits the curve. Fig.5 presents the relationship of the amplitude of order 72 (order of gearbox meshing) with the 4th order polynomial (red line). The points determined with the use of order analysis are marked in grey. Grey lines are the boundaries of the determined confidence intervals (for $N=15$ ). It can be noticed that the fit with the 4th order polynomial is not sufficient because a part of the curve lies outside the confidence interval. However, the fit with the 5 th order polynomial (black line) is within the confidence level. The selection of the polynomial fit order can be accomplished by an automated method.

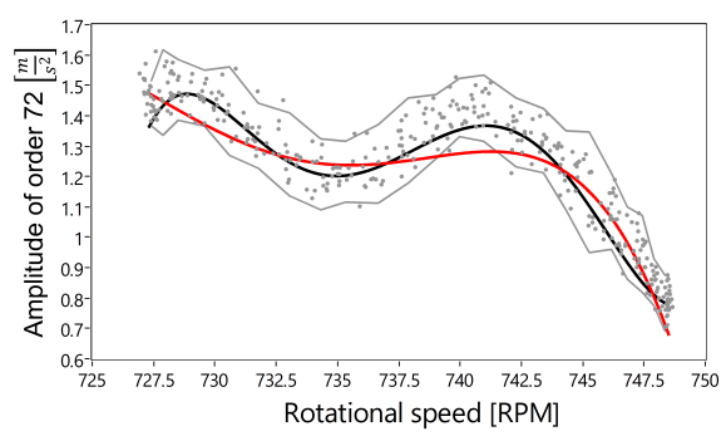

Fig. 5. Amplitude of mesh order (No. 72) of vibration acceleration (cross shaft direction) as a function of rotational speed, fit with the 4th order polynomial (red

line), fit with the 5 th order polynomial (black line)

According to the literature [9], the oil viscosity has a significant impact on the vibration generated by gearboxes. This paper focuses on the impact of oil type on the amplitudes of characteristic order of a planetary gearbox which were determined based on the gearbox design parameters. The tooth-mesh frequency of a planetary gearbox with immobilized ring can be determined from relationship (1). The rotational speed on the output shaft was measured, so taking into account the gearbox ratio, the toothmesh frequency can be calculated using the formula (2)

$$
f_{M}=f_{I N} \frac{z_{S} z_{R}}{z_{S}+z_{R}}
$$




$$
f_{M}=i f_{\text {oUT }} \frac{z_{S} z_{R}}{z_{S}+z_{R}}
$$

where:

$f_{I N} \quad$ - input shaft rotation frequency,

$f_{\text {OUT }}$ - output shaft rotation frequency,

$i$ - gearbox ratio,

$z_{S} \quad-$ number of teeth in sun gear,

$z_{R} \quad$ - number of teeth in ring gear.

Based on relationship (2), we can determine the number of the order carrying the information about the meshing determined relative to the output shaft rotation:

$$
O_{M}=i \frac{z_{S} z_{R}}{z_{S}+z_{R}}=72
$$

The order connected with the rotation of gearbox carrier relative the output shaft rotation can be determined from relationship (4):

$$
O_{C}=i \frac{z_{S}}{z_{S}+z_{R}}=1
$$

In the analysed case, the gearbox operates as a reducer, so the carrier is connected to the output shaft. The characteristic order for the carrier in this case is 1 .

The vibroacoustic signal also has the modulation frequencies which are related to the passing of planet gears through the measuring point [23]. The order related to this frequency can be expressed with the formula (5). This order is also characteristic for local ring gear damage:

$$
O_{P M o d}=O_{R L o c a l}=i \frac{z_{S} s}{z_{S}+z_{R}}=3
$$

where $s$ is number of planet gears.

The next characteristic orders of the diagnosed gearbox are presented below:

- order of local sun gear damage:

$$
O_{\text {SLocal }}=i \frac{z_{R} s}{z_{S}+z_{R}}=9
$$

- order of local planet gear damage:

$$
O_{\text {PLocal }}=i \frac{z_{S} z_{R}}{z_{R}^{2}+z_{S}^{2}}=4,8
$$

\section{DATA ANALYSIS RESULTS}

First, determined were the root-mean square (RMS) values of vibration accelerations for the gearbox with dedicated oil (ISO 150) and the reduced-viscosity oil (5W40). Table 2 presents the RMS acceleration values measured in three axes for both oil types. The RMS acceleration values increased by $19 \%$ for the reduced-viscosity oil in comparison with the gear oil. In most monitoring systems, such increase might not be treated as information about incorrect operation.

Table 2. RMS values of vibration acceleration
\begin{tabular}{|c|c|c|c|c|c|c|}
\hline \multirow{4}{*}{$\begin{array}{c}\text { Viscosity } \\
\text { class }\end{array}$} & $\begin{array}{c}\text { RMS }\left[\mathrm{m} / \mathrm{s}^{2}\right] \\
\text { along shaft }\end{array}$ & \multicolumn{2}{c|}{$\begin{array}{c}\text { RMS }\left[\mathrm{m} / \mathrm{s}^{2}\right] \\
\text { cross shaft } \\
\text { horizontally }\end{array}$} & \multicolumn{2}{c|}{$\begin{array}{c}\text { RMS }\left[\mathrm{m} / \mathrm{s}^{2}\right] \\
\text { cross shaft } \\
\text { vertically }\end{array}$} \\
\cline { 2 - 8 } & $\begin{array}{c}\text { sin. } \\
\text { load }\end{array}$ & $\begin{array}{c}\text { KWK } \\
1500 \mathrm{~s} \\
\text { load }\end{array}$ & $\begin{array}{c}\text { sin. } \\
\text { load }\end{array}$ & $\begin{array}{c}\text { KWK } \\
1500 \mathrm{~s} \\
\text { load }\end{array}$ & $\begin{array}{c}\text { sin. } \\
\text { load }\end{array}$ & $\begin{array}{c}\text { KWK } \\
1500 \mathrm{~s} \\
\text { load }\end{array}$ \\
\hline ISO 150 & 13.3 & 13.6 & 11.5 & 11.9 & 6.3 & 6.3 \\
\hline 5 W40 & 15.7 & 15.5 & 13.5 & 13.9 & 7.5 & 7.6 \\
\hline
\end{tabular}

The increase of RMS vibration acceleration values measured on the gearbox housing can take place in case of various damage and does not indicate a specific defect. The RMS values of the gear mesh frequency band were also analysed. For rotational speed changes in the range of 726-748 [rpm], the mesh frequency band is $871-899[\mathrm{~Hz}]$. The RMS values for the mesh frequency band are shown in Table 3. It is worth noting that the RMS values are lower for the lower oil viscosity for the directions across the shaft.

Table 3. RMS values of vibration acceleration of the mesh frequency band

\begin{tabular}{|c|c|c|c|c|c|c|}
\hline \multirow{2}{*}{$\begin{array}{c}\text { Viscosity } \\
\text { class }\end{array}$} & $\begin{array}{c}\text { RMS } \\
\text { of mesh } \\
\text { frequency } \\
\text { band }\left[\mathrm{m} / \mathrm{s}^{2}\right] \\
\text { along shaft }\end{array}$ & $\begin{array}{c}\text { RMS } \\
\text { of mesh } \\
\text { frequency } \\
\text { band }\left[\mathrm{m} / \mathrm{s}^{2}\right] \\
\text { cross shaft } \\
\text { horizontally }\end{array}$ & $\begin{array}{c}\text { RMS } \\
\text { of mesh } \\
\text { frequency } \\
\text { band }\left[\mathrm{m} / \mathrm{s}^{2}\right] \\
\text { cross shaft } \\
\text { vertically }\end{array}$ \\
\cline { 2 - 8 } & $\begin{array}{c}\text { sin. } \\
\text { load }\end{array}$ & $\begin{array}{c}\text { KWK } \\
1500 \mathrm{~s} \\
\text { load }\end{array}$ & $\begin{array}{c}\text { sin. } \\
\text { load }\end{array}$ & $\begin{array}{c}\text { KWK } \\
1500 \mathrm{~s} \\
\text { load }\end{array}$ & $\begin{array}{c}\text { sin. } \\
\text { load }\end{array}$ & $\begin{array}{c}\text { KWK } \\
1500 \mathrm{~s} \\
\text { load }\end{array}$ \\
\hline ISO 150 & 3.18 & 3.44 & 1.25 & 1.33 & 0.76 & 0.71 \\
\hline 5W40 & 3.97 & 3.45 & 0.93 & 1.90 & 0.52 & 0.44 \\
\hline
\end{tabular}

The characteristic orders should be analysed in order to identify the damage. The changes of relationship of the mesh order (No. 72) for oils ISO 150 and 5W40 were examined using the algorithm described in Section 4. The results are surprising, as for the low viscosity oil (5W40) the mesh order amplitude is lesser than for the dedicated oil (ISO 150), as seen in Fig. 6.

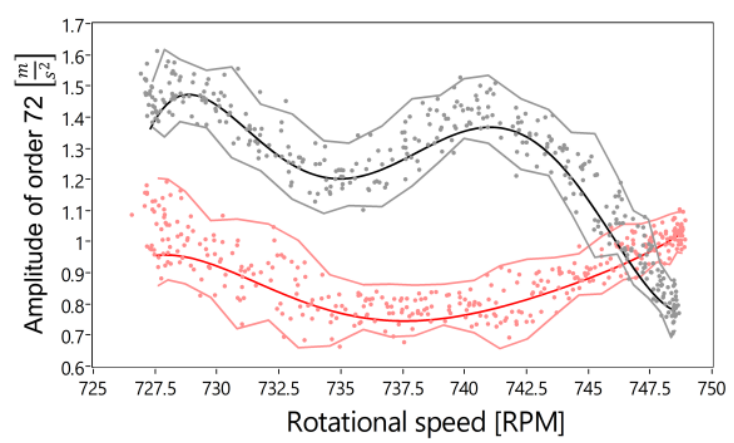

Fig. 6. Amplitude of mesh order (No. 72) of vibration acceleration (cross shaft direction) for ISO 150 oil (black) and 5W40 oil (red)

The situation is quite different, however, when we analyse the sidebands (order No. 69 and 75) of the mesh order created as a result of planet gears passing through the measurement point (Fig.7, 
Fig.8). For low rotational speeds, which correspond to the greatest load, the amplitudes of orders are threefold greater for the low-viscosity oil. If the system was analysed under load corresponding to the output shaft speed of 745 [rpm], the amplitude changes for modulating orders would not be visible. The analysis of amplitude values over the entire range of rotational speed changes caused by the load variation gives more information than the analysis of the order spectrum which contains averaged amplitude values in the analysed time window.

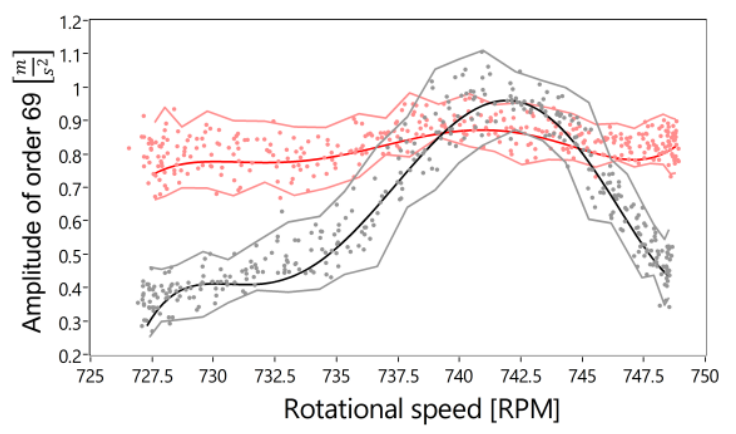

Fig. 7. Amplitude of modulating order (No. 69) of vibration acceleration (cross shaft direction) for ISO 150 oil (black) and 5W40 oil (red) - sinusoidal load

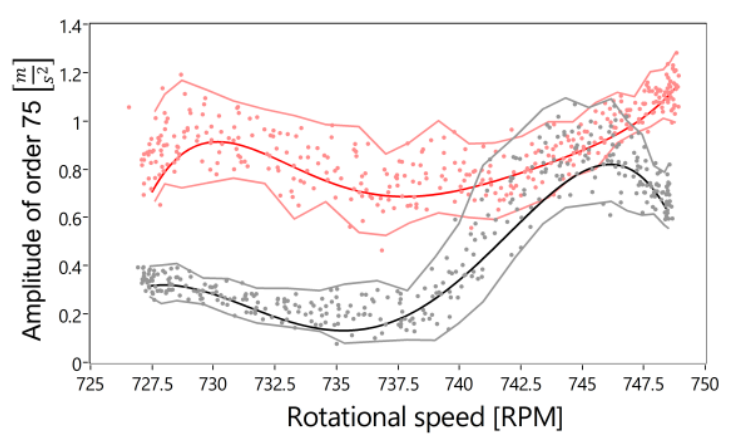

Fig. 8. Amplitude of modulating order (No. 75) of vibration acceleration (cross shaft direction) for ISO 150 oil (black) and 5W40 oil (red) - sinusoidal load

The situation is similar for the load of the main gearbox of the KWK 1500s excavator. The trend of amplitude changes as a function or rotational speed (Fig.9, Fig.10) is similar to that of the sinusoidal load.

In classical diagnostics, any deviations from component characteristic amplitudes recorded during a correct operation can be treated as an incorrect operation. In the proposed method, instead observing the average amplitude of characteristic order determined from the order spectrum for a given time window, the deviations from the standard relationship between the order amplitude and the load are observed. This relationship can be described with a standard curve recorded during the correct operation. In this case, the standard curve will be the relationship recorded for the dedicated gear oil Mobil SHC 629 of ISO 150 viscosity class.

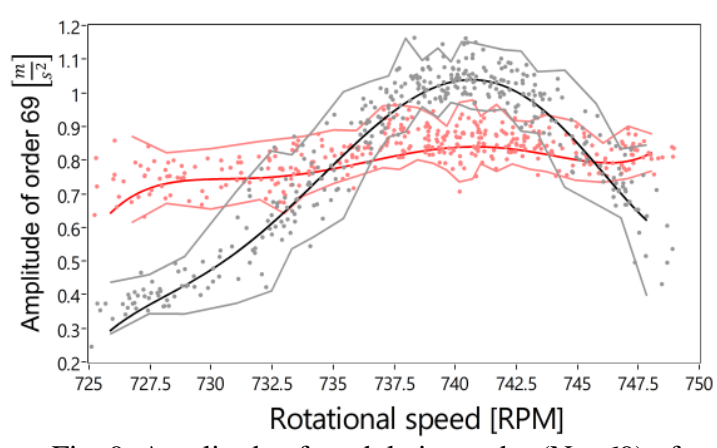

Fig. 9. Amplitude of modulating order (No. 69) of vibration acceleration (cross shaft direction) for ISO 150 oil (black) and 5W40 oil (red) - KWK 1500s load

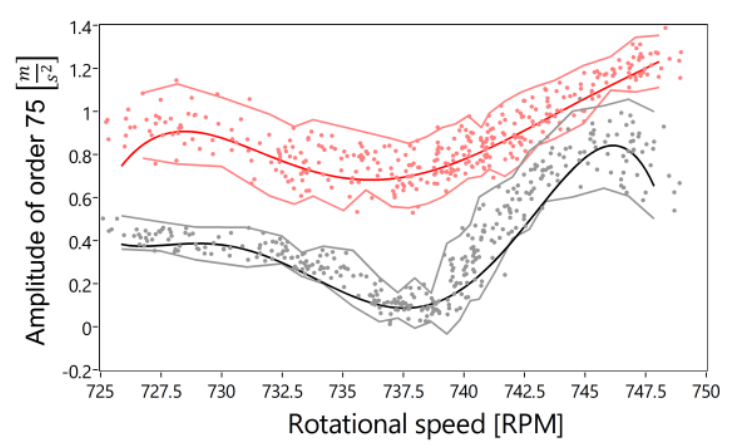

Fig. 10. Amplitude of modulating order (No. 75) of vibration acceleration (cross shaft direction) for ISO 150

oil (black) and 5W40 oil (red) - KWK 1500s load

The deviations from the standard curve can be parameterized using the root-mean-square deviation (RMSD) defined as [20]:

$$
R M S D(r)=\sqrt{\frac{1}{N} \sum_{s=1}^{N}\left(A(r, s)-A_{G}(r, s)\right)^{2}}
$$

$A_{G}(r, s)$ - standard amplitude for current rotational speed $(s)$ of the $r$ th order, determined from functional relationship $\left[\mathrm{m} / \mathrm{s}^{2}\right]$;

$A(r, s)$ - current amplitude for current rotational speed $(s)$ of the $r$ th order, determined from the functional relationship $\left[\mathrm{m} / \mathrm{s}^{2}\right]$.

The other proposed parameter is the maximum difference for the entire range of rotational speeds:

$$
\Delta A(r)_{\max }=\left|A(r, s)-A_{G}(r, s)\right|_{\max }
$$

To make these parameters independent of the vibration values, normalized measures were introduced in which the difference between the current and standard amplitudes has been divided by the standard amplitude:

$$
\begin{gathered}
R M S D(r)=\sqrt{\frac{1}{N} \sum_{s=1}^{N}\left(\frac{A(r, s)-A_{G}(r, s)}{A_{G}(r, s)}\right)^{2}} \\
\Delta A(r)_{\max }=\left|\frac{A(r, s)-A_{G}(r, s)}{A_{G}(r, s)}\right|_{\max }
\end{gathered}
$$

Tables 4 and 5 include the statistical parameters for orders modulating the mesh order. The parameters were determined for the $5 \mathrm{~W} 40$ oil in reference to the ISO 150 oil. Parameters $R M S D$ and $\Delta A_{\max }$ are expressed in acceleration units $\left[\mathrm{m} / \mathrm{s}^{2}\right]$. 
Parameters $r R M S D$ and $r \Delta A_{\max }$ are relative and are equal to 0 when there are no differences between the curves, and are equal to 1 when the values have changed by $100 \%$ in relation to the standard curve.

Table 4. Parameters determined for modulating order (No. 69) for 5W40 oil and after pouring the ISO 150 oil again in relation to the dedicated ISO 150 oil

\begin{tabular}{|c|c|c|c|c|c|}
\hline & & $\begin{array}{c}R M S D_{(69)} \\
{\left[\mathrm{m} / \mathrm{s}^{2}\right]}\end{array}$ & $\begin{array}{c}\Delta A_{\max (69)} \\
{\left[\mathrm{m} / \mathrm{s}^{2}\right]}\end{array}$ & $\begin{array}{c}r R M S D_{(69)} \\
{[-]}\end{array}$ & $\begin{array}{c}r \Delta A_{(69) \max } \\
{[-]}\end{array}$ \\
\hline \multirow{2}{*}{$\begin{array}{c}\text { sin. } \\
\text { load }\end{array}$} & $5 \mathrm{~W} 40$ & 0.54 & 0.40 & 0.24 & 1.12 \\
\cline { 2 - 6 } & ISO 150 & 0.05 & 0.08 & 0.04 & 0.09 \\
\hline $\begin{array}{c}\text { KWK } \\
1500 \mathrm{~s} \\
\text { load }\end{array}$ & $5 \mathrm{~W} 40$ & 0.27 & 0.30 & 0.16 & 0.72 \\
\cline { 2 - 6 } & ISO 150 & 0.04 & 0.04 & 0.03 & 0.08 \\
\hline
\end{tabular}

Table 5. Parameters determined for modulating order (No. 75) for $5 \mathrm{~W} 40$ oil and after pouring the ISO 150 oil again in relation to the dedicated ISO 150 oil

\begin{tabular}{|c|c|c|c|c|c|}
\hline & & $\begin{array}{c}R M S D_{(69)} \\
{\left[\mathrm{m} / \mathrm{s}^{2}\right]}\end{array}$ & $\begin{array}{c}\Delta A_{\max (69)} \\
{\left[\mathrm{m} / \mathrm{s}^{2}\right]}\end{array}$ & $\begin{array}{c}r R M S D_{(69)} \\
{[-]}\end{array}$ & $\begin{array}{c}r \Delta A_{(69) \max } \\
{[-]}\end{array}$ \\
\hline \multirow{2}{*}{$\begin{array}{c}\text { sin. } \\
\text { load }\end{array}$} & $5 \mathrm{~W} 40$ & 2.48 & 0.66 & 0.47 & 4.57 \\
\cline { 2 - 6 } & ISO 150 & 0.04 & 0.08 & 0.02 & 0.11 \\
\hline $\begin{array}{c}\text { KWK } \\
\text { 1500s } \\
\text { load }\end{array}$ & $5 \mathrm{~W} 40$ & 2.80 & 0.60 & 0.48 & 6.25 \\
\cline { 2 - 6 } & ISO 150 & 0.08 & 0.07 & 0.03 & 0.16 \\
\hline
\end{tabular}

For the sinusoidal load, the parameter $r \Delta A_{(69) \max }$ for order 69 is 1.12, indicating the maximum change of the curve by $112 \%$ for the $5 \mathrm{~W} 40$ oil relative to ISO 150 . The same parameter for order 75 is 4.57 which indicates that the amplitude of vibration acceleration order has increased more than fourfold. In the monitoring systems, a fourfold increase is a significant value.

In case of random load occurring in the main gearbox of the KWK 1500s excavator, all parameters also increase in relation to the parameters obtained after pouring the dedicated oil again (ISO 150). Similarly to the sinusoidal load, the largest increase is for parameter $r \Delta A_{(75) \max }$.

\section{SUMMARY}

A method based on the analysis of changes of amplitudes of characteristic orders as a function of load was used to determine the impact of oil on the vibroacoustic signal. In the prosed method, instead observing the average amplitude of characteristic order determined from the order spectrum for a given time window, the deviations from the standard relationship between the order amplitude and the load are observed. This relationship can be described with a standard curve recorded during the correct operation. These relationships were expressed in the paper as a 5th order polynomial. The analysis of amplitude values over the entire range of rotational speed changes caused by the load variation gives more information than the analysis of the order spectrum which contains averaged amplitude values in the analysed time window.

In the paper, determined were standard curves from the vibration acceleration signal for the dedicated gear oil Mobil SHC 629 (ISO 150) for the planetary gearbox mesh order and sidebands created as a result of planet gears passing through the measurement point. Then, determined were the curves for the oil with significantly lower viscosity - Elf Evolution 900 SXR (5W40). Differences were observed in the shape of polynomial curves obtained for various oil types. The deviations from standard curves were presented as statistical parameters $R M S D, \triangle A_{\max }, r R M S D$ and $r \Delta A_{\max }$. The values of these parameters were substantial when the lower-viscosity oil was used, indicating a significant change of the analysed characteristic orders.

The method effectiveness was analysed for the sinusoidal load and the random load similar to that of the main gearbox in the bucket wheel of the KWK1500s excavator used in heavy industry. Similar results were obtained for both load types.

\section{SOURCE OF FUNDING}

The research financed from the Research Subvention No. 16.16.130.942.

\section{REFERENCES}

1. Liu H, Liu H, Zhu C, Parker RG. Effects of lubrication on gear performance: A review. Mechanism and Machine Theory 2020;145:103701. https://doi.org/10.1016/j.mechmachtheory.2019.1037 $\underline{01}$

2. Marques PMT, Fernandes CMCG, Martins RC, Seabra JHO. Efficiency of a gearbox lubricated with wind turbine gear oils. Tribology International 2014;71:7-16. https://doi.org/10.1016/j.triboint.2013.10.017

3. Moss J, Kahraman A, Wink C. An experimental study of influence of lubrication methods on efficiency and contact fatigue life of spur gears. Journal of Tribology 2018;140. https://doi.org/10.1115/1.4039929

4. Skoć A, Kwaśny M. Wpływ sposobu smarowania na międzyzębne siły dynamiczne w przekładni zębatej stożkowej (Influence of the method of lubrication on inter-tooth dynamic loads in conical gear) 2018:74-8.

5. Russo R, Brancati R, Rocca E. Experimental investigations about the influence of oil lubricant between teeth on the gear rattle phenomenon. Journal of Sound and Vibration 2009;321:647-61. https://doi.org/10.1016/j.jsv.2008.10.008

6. Wilk A, Madej H, Figlus T. Analysis of the possibility to reduce vibroactivity of the gearbox housing. Eksploatacja i Niezawodnosc - Maintenance and Reliability 2011;50:42-9.

7. Dąbrowski Z, Dziurdź J, Klekot G. Influence of the mesh geometry evolution on gearbox dynamics during its maintenance. International Journal of Applied Mechanics and Engineering 2017;22:1097105. https://doi.org/10.1515/ijame-2017-0071 
8. Figlus T, Wilk A, Madej H, Lazarz B. Investigation of gearbox vibroactivity with the use of vibration and acoustic pressure start-up characteristics. Archive of Mechanical Engineering 2011;58:209-21. https://doi.org/10.2478/v10180-011-0015-5

9. Spałek J, Kwaśny M. Diagnostyczna weryfikacja wpływu lepkości oleju smarującego na pracę przekładni zębatej (Diagnostic verification of the use of oil to lubricate toothed gear). Szybkobieżne Pojazdy Gąsienicowe 2012;29:75-80.

10. Randall RB. Frequency Analysis. Nærum: Bruel \& Kjær; 1987.

11. Braun SG, Seth BB. On the extraction and filtering of signals acquired from rotating machines. Journal of Sound and Vibration 1979;65:37-50. https://doi.org/10.1016/0022-460X(79)90526-1

12. Gade S, Herlufsen H, Konstantin-Hansen H, Wismer NJ. Order Tracking Analysis. Technical Review, Nærum: Brüel \& Kjær; 1995, p. 51.

13. Cioch W, Krzyworzeka P. Vibration analysis of running-up turbine engine GTD-350. Diagnostyka 2007;4:125-30.

14. Burdzik R, Konieczny $Ł$, Warczek J, Cioch W. Adapted linear decimation procedures for TFR analysis of non-stationary vibration signals of vehicle suspensions. Mechanics Research Communications 2017;82:29-35. https://doi.org/10.1016/j.mechrescom.2016.11.002.

15. Cheng W, Gao RX, Wang J, Wang T, Wen W, Li J. Envelope deformation in computed order tracking and error in order analysis. Mechanical Systems and Signal Processing 2014;48:92-102. https://doi.org/10.1016/j.ymssp.2014.03.004

16. Bonnardot F, El Badaoui M, Randall RB, Danière J, Guillet $F$. Use of the acceleration signal of a gearbox in order to perform angular resampling (with limited speed fluctuation). Mechanical Systems and Signal Processing 2005;19:766-85. https://doi.org/10.1016/j.ymssp.2004.05.001

17. Guo Y, Tan KK. Order-crossing removal in Gabor order tracking by independent component analysis. Journal of Sound and Vibration 2009;325:471-88. https://doi.org/10.1016/j.jsv.2009.03.003

18. Pawlik P, Lepiarczyk D, Dudek R, Ottewill JR, Rzeszuciński P, Wójcik M, et al. Vibroacoustic study of powertrains operated in changing conditions by means of order tracking analysis. Eksploatacja i Niezawodnosc - Maintenance and Reliability 2016;18:606-12. https://doi.org/10.17531/ein.2016.4.16

19. Popiołek K, Pawlik P. Diagnosing the Technical Condition of Planetary Gearbox Using the Artificial Neural Network Based on Analysis of NonStationary Signals. Diagnostyka 2016;17:57-64.

20. Pawlik P. Single-number statistical parameters in the assessment of the technical condition of machines operating under variable load. Eksploatacja i Niezawodnosc - Maintenance and Reliability 2019; 21:164-9. https://doi.org/10.17531/ein.2019.1.19

21. Pawlik P. The Use of the Acoustic Signal to Diagnose Machines Operated Under Variable Load. Archives of Acoustics 2020;45:263-70. https://doi.org/10.24425/aoa.2020.133147

22. Pawlik P. The diagnostic method of rolling bearing in planetary gearbox operating at variable load. Diagnostyka 2019;20:69-77. https://doi.org/10.29354/diag/111567

23. Bartelmus W, Zimroz RR. Vibration spectra characteristic frequencies for condition monitoring of mining machinery compound and complex gearboxes. Prace Naukowe Instytutu Górnictwa Politechniki Wrocławskiej 2011;40:17-34.

\section{Received 2020-07-03 \\ Accepted 2020-10-26 \\ Available online 2020-11-09}

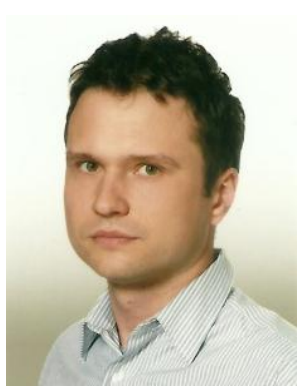

Pawel PAWLIK, received $\mathrm{PhD}$ degree in Faculty of Mechanical Engineering and Robotics from AGH University of Science and Technology, Cracow, Poland, in 2013. In the scientific work he builds vibrodiagnostic monitoring systems and develops methods of signals processing. $\mathrm{He}$ is also involved in the development of non-classical methods of uncertainty assessment. 